ISSN 0258-7122 (Print), 2408-8293 (Online)

Bangladesh J. Agril. Res. 43(3): 441-451, September 2018

\title{
EFFECTS OF ZINC AND BORON ON YIELD, NODULATION AND NUTRIENT CONTENTS OF FIELDPEA IN TERRACE SOILS
}

\author{
M. A. QUdDUS ${ }^{1}$, M. A. HoSSAIN ${ }^{2}$, H. M. NASER ${ }^{3}$ AND S. AKHTAR ${ }^{4}$
}

\begin{abstract}
An experiment was conducted for two consecutive years (2014-15 and 2015-16) in the field of Pulses Research Sub-Station, BARI, Gazipur during rabi (winter) season to evaluate the effect of zinc (Zn) and boron (B) application on the yield, nodulation and nutrient content of fieldpea (Pisum sativum $\mathrm{L}$.). There were 16 treatment combinations comprising four levels each of zinc $\left(0,1,2\right.$ and $\left.3 \mathrm{~kg} \mathrm{ha}^{-1}\right)$ and boron $\left(0,1,1.5\right.$ and $\left.2 \mathrm{~kg} \mathrm{ha}^{-1}\right)$ along with a blanket dose of $\mathrm{N}_{12} \mathrm{P}_{18} \mathrm{~K}_{30} \mathrm{~S}_{10}$ $\mathrm{kg} \mathrm{ha}^{-1}$ over the treatments. The experiment was laid out in a split-plot design with three replications. Zinc ( $\mathrm{Zn})$ as $\mathrm{ZnSO}_{4} .7 \mathrm{H}_{2} \mathrm{O}$ and boron (B) as $\mathrm{H}_{3} \mathrm{BO}_{3}$ were applied to the crop (cv. BARI Fieldpea-1). Results showed that the combination of $\mathrm{Zn}_{3} \mathrm{~B}_{1.5} \mathrm{~kg} \mathrm{ha}^{-1}$ produced the highest seed yield $\left(1582 \mathrm{~kg} \mathrm{ha}^{-1}\right)$ in the $1^{\text {st }}$ year and the $\mathrm{Zn}_{3} \mathrm{~B}_{2} \mathrm{~kg} \mathrm{ha}^{-1}$ gave the highest yield $\left(1702 \mathrm{~kg} \mathrm{ha}^{-1}\right)$ in the $2^{\text {nd }}$ year.The lowest seed yield was found in the control $\left(\mathrm{Zn}_{0} \mathrm{~B}_{0}\right)$. The $\mathrm{Zn}_{3} \mathrm{~B}_{2}$ demonstrated the highest nodulation and nutrient and protein contents. The results suggest that the application of $\mathrm{Zn}_{3} \mathrm{~B}_{2} \mathrm{~kg} \mathrm{ha}^{-1}$ along with $\mathrm{N}_{12} \mathrm{P}_{18} \mathrm{~K}_{30} \mathrm{~S}_{10} \mathrm{~kg} \mathrm{ha}^{-1}$ can support the higher yield of fieldpea in terrace soils of Bangladesh.
\end{abstract}

Keywords: Zinc and boron, fieldpea, yield, nodulation, nutrient content

\section{Introduction}

Field pea (Pisum sativum $\mathrm{L}$ ) is a popular legume crop worldwide. Fieldpea is rich in high-quality protein (20\%), contains $4 \mathrm{mg}$ pro-vitamin $\mathrm{A}, 300 \mathrm{mg}$ vitamin $\mathrm{C}, 3$ $\mathrm{mg} \mathrm{B}_{1}, 1.5 \mathrm{mg} \mathrm{B}_{2}$ and $1.2 \mathrm{mg}$ pantothenic acid per $1000 \mathrm{~g}$ fresh seed weight and also it contains $1.1 \%$ fat, $2.2 \%$ minerals, $4.5 \%$ fiber and $56.5 \%$ carbohydrate (Dixit, 2002). Besides, fieldpea improves soil health through biological nitrogen fixation (about 30-50 $\mathrm{kg} \mathrm{N} \mathrm{ha}^{-1}$ ) and addition of organic matter to the soil (Erman et al., 2009).

The yield of pulses including fieldpea in Bangladesh is low as because it is usually cultivated in less fertile soil. As a micronutrient, $\mathrm{Zn}$ and B are deficient in this country's soil. This crop (fieldpea) is less tested in terrace soils which exist in the Barind and Madhupur tracts. They are acidic in reaction with low organic matter, moisture holding capacity and fertility level. The soils are mainly phosphate fixing, and low in P, K, S, Zn and B levels (Rashid, 2001; FRG, 2012).

${ }^{1}$ Senior Scientific Officer, Horticulture Research Centre, Bangladesh Agricultural Research Institute (BARI), Gazipur, ${ }^{2}$ Chief Scientific Officer, ${ }^{3}$ Principal Scientific Officer, ${ }^{2,3}$ Soil Science Division, BARI, Gazipur, ${ }^{4}$ Scientific Officer, Pulses Research Sub-Station, BARI, Gazipur, Bangladesh. 
Zinc and B deficiency is widespread in the country; specifically B deficiency is more common in rabi crops (Jahiruddin, 2015). Zinc plays a vital role in metabolism and is known to be involved in $\mathrm{N}$-fixation through nodule formation (Patel et al., 2011). Boron influences the absorption of $\mathrm{N}, \mathrm{P}, \mathrm{K}$ and its deficiency changed the equilibrium of optimum of those three macronutrients (Raj, 1985).

Hence, balance application of micronutrient along with macro nutrients may render good possibility to increase fieldpea production as well as improve soil fertility. The present study was therefore, undertaken (i) to evaluate the effect of $\mathrm{Zn}$ and $\mathrm{B}$ on yield, nodulation and nutrient content of fieldpea; and (ii) to find out the suitable combination of $\mathrm{Zn}$ and $\mathrm{B}$ for yield maximization of fieldpea.

\section{Materials and Methods}

A field experiment was conducted for two consecutive years (2014-15 and 201516 at winter) in the research field of Pulses Research Sub-Station (PRSS), Bangladesh Agricultural Research Institute (BARI), Joydebpur, Gazipur. The terrace soils of Gazipur is medium high land with fine-textured (clay loam) and belongs to Chhiata series (Soil taxonomy: Udic Rhodustalf) under the agroecological zone - Madhupur Tract (AEZ-28). Before beginning the experiment initial soil $(0-15 \mathrm{~cm})$ sample was collected from the field and analysed for chemical properties. The soil contains $6.6 \mathrm{pH}, 1.26 \%$ organic matter, $0.057 \%$ N, 15.5 ppm P, 16 ppm S, 0.8 ppm Zn and 0.17 ppm B.

There were 16 treatment combinations comprising four levels each of $\mathrm{Zn}(0,1,2$ and $\left.3 \mathrm{~kg} \mathrm{ha}^{-1}\right)$ and four levels of $\mathrm{B}\left(0,1,1.5\right.$ and $\left.2 \mathrm{~kg} \mathrm{ha}^{-1}\right)$. The blanket dose was $\mathrm{N}_{12}$ $\mathrm{P}_{18} \mathrm{~K}_{30} \mathrm{~S}_{10} \mathrm{~kg} \mathrm{ha}^{-1}$. The experiment was laid out in split-plot design with three replications. The unit plot size was $4 \mathrm{~m} \times 3 \mathrm{~m}$. Zinc and B were applied as zinc sulphate and boric acid, respectively. Every plot received an equal amount of fertilizers at $\mathrm{N}_{12} \mathrm{P}_{18} \mathrm{~K}_{30} \mathrm{~S}_{10} \mathrm{~kg} \mathrm{ha}^{-1}$ (FRG, 2012) as urea, TSP, MoP and gypsum during final plot preparation. Seeds of fieldpea cv BARI Fieldpea-1 were sown @ $30 \mathrm{~kg} \mathrm{ha}^{-1}$ with a spacing of $40 \mathrm{~cm} \times 05 \mathrm{~cm}$ on 12 November 2014 and 10 November 2015. Two hand weedings were done at 25 and 50 days after sowing. Diseases and insects were controlled properly. The crop was harvested after maturity. The data of nodule per plant was recorded from 5 randomly selected plants in each plot. Stover yield $\left(\mathrm{kg} \mathrm{ha}^{-1}\right)$ was measured from two places in each plot over one square meter. Seed yield $\left(\mathrm{kg} \mathrm{ha}^{-1}\right)$ was recorded from the whole plot technique.

Treatment-wise plant samples (stover and seed) against each treatment plot were oven-dried at $70^{\circ} \mathrm{C}$ for $48 \mathrm{~h}$ and finely ground.

The initial soil sample was analyzed for soil $\mathrm{pH}$ was measured by glass electrode pH meter using soil:water ratio of 1:2.5 (Page et al., 1982) and organic matter by 
Nelson and Sommers (1982) method; total N (Bremner and Mulvaney, 1982); exchangeable $\mathrm{K}$ by $1 \mathrm{~N} \mathrm{NH}_{4} \mathrm{OAc}$ method (Jackson, 1973); available P by Bray and Kurtz (1945) method; available $\mathrm{S}$ by turbidity method using $\mathrm{BaCl}_{2}$ (Fox et al., 1964); available Zn by DTPA method (Lindsay and Norvell, 1978); available B by azomethine-H method (Page et al., 1982).

Ground plant sample (stover and seeds) was analysed for $\mathrm{N}$ using the Kjeldahl method FOSS (Persson et al., 2008). Ground plant samples (seed and stover) were digested with di-acid mixture $\left(\mathrm{HNO}_{3}-\mathrm{HClO}_{4}\right)(5: 1)$ as described by Piper (1966) for the determination- content of $\mathrm{P}$ (spectrophotometer method), $\mathrm{K}$ (atomic absorption spectrophotometer method), $\mathrm{S}$ (turbidity method using $\mathrm{BaCl}_{2}$ by spectrophotometer), $\mathrm{Zn}$ (atomic absorption spectrophotometer method) and $\mathrm{B}$ (spectrophotometer following azomethine-H method).

Protein content in fieldpea seed was calculated on considering the pulses food factor 5.30 (FAO, 2018). Protein content was measured by multiplying the $\% \mathrm{~N}$ content of seed with pulses food factor 5.30 that means $(\% \mathrm{~N} \times 5.30)$.

Analysis of variance (ANOVA) for the yield, nodulation, different nutrient and protein content was done following the Statistix 10 package (Statistix 10. 1985). The least significant difference (LSD) at 5\% level was used to compare the treatments means.

\section{Results and Discussion}

\section{Effects of zinc and boron on crop yields}

The interaction effect of $\mathrm{Zn}$ and $\mathrm{B}$ on the yields of fieldpea was observed statistically significant during two consecutive years (Table 1). The crop responded to $\mathrm{Zn}$ and $\mathrm{B}$ application since the experimental soil was deficient zinc and boron. Similar findings were reported by Agrawal and Sharma (2005). Results showed that the mean seed yield varied from $920 \mathrm{~kg} \mathrm{ha}^{-1}$ to $1631 \mathrm{~kg}$ ha ${ }^{1}$ depending on the treatments. The highest seed yield of $1582 \mathrm{~kg} \mathrm{ha}^{-1}$ in $1^{\text {st }}$ year was obtained from $\mathrm{Zn}_{3} \mathrm{~B}_{1.5} \mathrm{~kg} \mathrm{ha}^{-1}$ and $1702 \mathrm{~kg} \mathrm{ha}^{-1}$ in the $2^{\text {nd }}$ year from $\mathrm{Zn}_{3} \mathrm{~B}_{2}$ $\mathrm{kg} \mathrm{ha}^{-1}$ treatment; however both the treatments were statistically similar to each other. The lowest seed yield was observed in control $\left(\mathrm{Zn}_{0} \mathrm{~B}_{0}\right)$ treatment. The stover yield (mean of two years) of fieldpea ranged from $2486 \mathrm{~kg} \mathrm{ha}^{-1}$ to 4310 $\mathrm{kg} \mathrm{ha}{ }^{-1}$ over the treatments. The $\mathrm{Zn}_{3} \mathrm{~B}_{2}$ treatment combination exhibited the highest stover yield in both years followed by the treatment of $\mathrm{Zn}_{3} \mathrm{~B}_{1.5} \mathrm{~kg} \mathrm{ha}^{-1}$ (Table 1). Micronutrient enhanced the survival and multiplication of microorganism, more nitrogen fixation, transport of sugars and better uptake and assimilation of available nutrients by the plants during the entire growth period for higher yields. Similar observations have been reported by Valenciano et al. (2010). 
Table 1. Combined effect of zinc and boron on the yields of fieldpea

\begin{tabular}{c|c|c|c|c|c|c}
\hline \multirow{2}{*}{ Treatment } & \multicolumn{3}{c}{ Seed yield $\left(\mathrm{kg} \mathrm{ha}^{-1}\right)$} & \multicolumn{3}{c}{ Stover yield $\left(\mathrm{kg} \mathrm{ha}^{-1}\right)$} \\
\cline { 2 - 7 } & $1^{\text {st }} \mathrm{yr}$ & $2^{\text {nd }} \mathrm{yr}$ & Mean & $1^{\text {st }} \mathrm{yr}$ & $2^{\text {nd }} \mathrm{yr}$ & Mean \\
\hline $\mathrm{Zn}_{0} \mathrm{~B}_{0}$ & $890 \mathrm{e}$ & 949 & 920 & 2475 & 2497 & 2486 \\
$\mathrm{Zn}_{0} \mathrm{~B}_{1}$ & 1126 & 1187 & 1157 & 3263 & 2995 & 3129 \\
$\mathrm{Zn}_{0} \mathrm{~B}_{1.5}$ & 1196 & 1283 & 1240 & 3350 & 3224 & 3287 \\
$\mathrm{Zn}_{0} \mathrm{~B}_{2}$ & 1126 & 1384 & 1255 & 3021 & 3416 & 3219 \\
$\mathrm{Zn}_{1} \mathrm{~B}_{0}$ & 1085 & 1163 & 1124 & 2967 & 3011 & 2989 \\
$\mathrm{Zn}_{1} \mathrm{~B}_{1}$ & 1158 & 1421 & 1290 & 3249 & 3612 & 3431 \\
$\mathrm{Zn}_{1} \mathrm{~B}_{1.5}$ & 1248 & 1528 & 1388 & 3445 & 3745 & 3595 \\
$\mathrm{Zn}_{1} \mathrm{~B}_{2}$ & 1277 & 1544 & 1411 & 3491 & 3831 & 3661 \\
$\mathrm{Zn}_{2} \mathrm{~B}_{0}$ & 1126 & 1306 & 1216 & 3263 & 3323 & 3293 \\
$\mathrm{Zn}_{2} \mathrm{~B}_{1}$ & 1297 & 1468 & 1383 & 3578 & 3629 & 3629 \\
$\mathrm{Zn}_{2} \mathrm{~B}_{1.5}$ & 1417 & 1549 & 1483 & 3802 & 3756 & 3779 \\
$\mathrm{Zn}_{2} \mathrm{~B}_{2}$ & 1408 & 1607 & 1508 & 3778 & 4005 & 3892 \\
$\mathrm{Zn}_{3} \mathrm{~B}_{0}$ & 1155 & 1375 & 1265 & 3194 & 3511 & 3353 \\
$\mathrm{Zn}_{3} \mathrm{~B}_{1}$ & 1291 & 1597 & 1444 & 3544 & 3898 & 3721 \\
$\mathrm{Zn}_{3} \mathrm{~B}_{1.5}$ & 1582 & 1680 & 1631 & 4015 & 4253 & 4134 \\
$\mathrm{Zn}_{3} \mathrm{~B}_{2}$ & 1513 & 1702 & 1608 & 4233 & 4387 & 4310 \\
\hline $\mathrm{CV}_{(\%} \%$ & 4.61 & 3.66 & - & 5.71 & 4.39 & - \\
$\mathrm{LSD}_{(0.05)}$ & 178 & 88 & - & 606 & 264 & - \\
\hline
\end{tabular}

\section{Effects of zinc and boron on nodulation}

The $\mathrm{Zn}$ and $\mathrm{B}$ treatments along with macro nutrients promoted the nodule formation. Combined application of $\mathrm{Zn}$ and $\mathrm{B}$ influenced significantly to produce good numbers of active nodule per plant (Table 2). Similar observation made by Chatterjee and Bandyopadhyay (2015). The number of nodules per plant counted at 32 DAS ranged from 7.98 to 15.1 across the treatments. Nodulations per plant at 47 DAS varied from 19.8 to 30.2, at 62 DAS from 24.8 to 38.6 and 77 DAS, nodulations varied from 17.9 to 27.1 . The maximum number of nodules per plant was counted on the treatment $\mathrm{Zn}_{3} \mathrm{~B}_{2}$ in all the dates except 77 DAS. The minimum number of nodule per plant was counted in control treatment $\left(\mathrm{Zn}_{0} \mathrm{~B}_{0}\right)$ over the collection dates (Table 2). Nodule formation was less in 32 DAS and 77 DAS and was more at 47 and 62 DAS. It appears that the highest number of nodule formation occurred during early to mid flowering stage. 
Table 2. Combined effect of zinc and boron on the number of nodules per plant of fieldpea at different dates (2-years pooled data)

\begin{tabular}{c|lll|l}
\hline Treatment & $\begin{array}{c}\text { No. of nodules } \\
\text { after 32 DAS }\end{array}$ & $\begin{array}{c}\text { No. of nodules } \\
\text { after 47 DAS }\end{array}$ & $\begin{array}{c}\text { No. of nodules } \\
\text { after 62 DAS }\end{array}$ & $\begin{array}{c}\text { No. of nodules } \\
\text { after 77 DAS }\end{array}$ \\
\hline $\mathrm{Zn}_{0} \mathrm{~B}_{0}$ & 7.98 & 19.8 & 24.8 & 17.9 \\
$\mathrm{Zn}_{0} \mathrm{~B}_{1}$ & 9.14 & 21.3 & 27.3 & 19.3 \\
$\mathrm{Zn}_{0} \mathrm{~B}_{1.5}$ & 9.25 & 22.4 & 27.1 & 20.5 \\
$\mathrm{Zn}_{0} \mathrm{~B}_{2}$ & 10.0 & 22.7 & 28.7 & 21.6 \\
$\mathrm{Zn}_{1} \mathrm{~B}_{0}$ & 9.39 & 21.6 & 27.1 & 22.1 \\
$\mathrm{Zn}_{1} \mathrm{~B}_{1}$ & 11.4 & 23.1 & 28.9 & 23.7 \\
$\mathrm{Zn}_{1} \mathrm{~B}_{1.5}$ & 12.1 & 23.9 & 30.1 & 25.6 \\
$\mathrm{Zn}_{1} \mathrm{~B}_{2}$ & 12.3 & 24.3 & 32.4 & 26.4 \\
$\mathrm{Zn}_{2} \mathrm{~B}_{0}$ & 10.6 & 23.7 & 29.8 & 23.3 \\
$\mathrm{Zn}_{2} \mathrm{~B}_{1}$ & 11.7 & 24.5 & 31.9 & 24.7 \\
$\mathrm{Zn}_{2} \mathrm{~B}_{1.5}$ & 12.4 & 25.7 & 33.7 & 27.1 \\
$\mathrm{Zn}_{2} \mathrm{~B}_{2}$ & 12.8 & 26.5 & 35.2 & 26.9 \\
$\mathrm{Zn}_{3} \mathrm{~B}_{0}$ & 11.4 & 23.4 & 31.6 & 25.7 \\
$\mathrm{Zn}_{3} \mathrm{~B}_{1}$ & 13.2 & 26.9 & 35.7 & 24.1 \\
$\mathrm{Zn}_{3} \mathrm{~B}_{1.5}$ & 14.3 & 28.7 & 37.9 & 25.1 \\
$\mathrm{Zn}_{3} \mathrm{~B}_{2}$ & 15.1 & 30.2 & 38.6 & 24.9 \\
\hline $\mathrm{CV}(\%)$ & 5.12 & 3.29 & 4.14 & 3.84 \\
$\mathrm{LSD}(0.05)$ & 0.99 & 1.35 & 2.18 & 1.53 \\
\hline & & &
\end{tabular}

\section{Effects of zinc and boron on nutrient content}

Application of $\mathrm{Zn}$ and B remarkedly influenced the N, protein, $\mathrm{P}, \mathrm{K}, \mathrm{S}, \mathrm{Zn}$ and B contents of fieldpea seed (Table 3). The $\mathrm{N}$ content due to different treatments ranged from 3.85 to $4.56 \%$, the highest $N$ content being found in $\mathrm{Zn}_{3} \mathrm{~B}_{2}$ which was statistically similar to $Z_{3} B_{1.5}, Z_{2} B_{2}, Z_{2} B_{1.5}, Z_{2} B_{1}$, and $Z_{1} B_{2}$ treatments. Different combination of $\mathrm{Zn}$ and $\mathrm{B}$ had a significant effect on protein content (\%) of fieldpea seed. The protein content varied between $20.4 \%$ and $24.1 \%$ over the treatments. The highest protein content $(24.1 \%)$ was noted for the treatment $\mathrm{Zn}_{3} \mathrm{~B}_{2} \mathrm{~kg} \mathrm{ha}^{-1}$ which was significantly different with the others treatments. The lowest protein content in seed $(20.4 \%)$ was calculated from $\mathrm{Zn}_{0} \mathrm{~B}_{0}$ treatment (Table 3). Márquez-Quiroz et al. (2015) reported that micronutrient application may enhance nutrition security through improving the grain quality in addition its role in increasing productivity. The $\mathrm{P}$ content in seed varied from 0.22 to $0.29 \%$ with the highest record in $\mathrm{Zn}_{3} \mathrm{~B}_{2}$ which was statistically identical to $\mathrm{Zn}_{3} \mathrm{~B}_{1.5}$, 
$\mathrm{Zn}_{3} \mathrm{~B}_{1}, \mathrm{Zn}_{2} \mathrm{~B}_{2}, \mathrm{Zn}_{2} \mathrm{~B}_{1.5}, \mathrm{Zn}_{3} \mathrm{~B}_{0}$ and $\mathrm{Zn}_{1} \mathrm{~B}_{2}$ treatments. The $\mathrm{K}$ and $\mathrm{S}$ contents in different treatments ranged from 0.35 to $0.45 \%$ and 0.08 to $0.16 \%$, respectively across the treatments. The maximum $\mathrm{K}$ content $(0.45 \%)$ was recorded in $\mathrm{Zn}_{3} \mathrm{~B}_{2}$ followed by $\mathrm{Zn}_{3} \mathrm{~B}_{1.5}, \mathrm{Zn}_{2} \mathrm{~B}_{2}$ and $\mathrm{Zn}_{2} \mathrm{~B}_{1.5}$ and the lowest $\mathrm{K}$ content was in control. The highest $S$ content $(0.16 \%)$ was observed in $\mathrm{Zn}_{3} \mathrm{~B}_{2}$ which was statistically similar at per $\mathrm{Zn}_{3} \mathrm{~B}_{1.5}, \mathrm{Zn}_{3} \mathrm{~B}_{1}, \mathrm{Zn}_{2} \mathrm{~B}_{2}$, and $\mathrm{Zn}_{2} \mathrm{~B}_{1.5}$ treatments. Regarding $\mathrm{Zn}$ and $\mathrm{B}$ contents in seed, it varied from 23.6 to $27.5 \mathrm{ppm}$ and 25.9 to $31.2 \mathrm{ppm}$, respectively. The maximum $\mathrm{Zn}(27.5 \mathrm{ppm})$ and $\mathrm{B}(31.2 \mathrm{ppm})$ contents were observed in $\mathrm{Zn}_{3} \mathrm{~B}_{2}$. The control $\left(\mathrm{Zn}_{0} \mathrm{~B}_{0}\right)$ gave the lowest nutrient contents (Table 3). Karim (2016) reported that combined application of $\mathrm{Zn}, \mathrm{B}$ and Mo contributed to higher nutrient contens $(5.04 \% \mathrm{~N}, 0.36 \% \mathrm{P}, 0.86 \% \mathrm{~K}, 0.34 \% \mathrm{~S}$, $72.4 \mathrm{ppm} \mathrm{Zn}$ and $41.5 \mathrm{ppm} \mathrm{B}$ ) in lentil seed.

Table 3. Combined effects of zinc and boron on N, protein, P, K, S, Zn and B contents of fieldpea seed (2-years pooled data)

\begin{tabular}{|c|c|c|c|c|c|c|c|}
\hline \multirow{3}{*}{ Treatment } & \multicolumn{7}{|c|}{ Nutrient content in seed } \\
\hline & $\mathrm{N}$ & Protein & $\mathrm{P}$ & K & $\mathrm{S}$ & $\mathrm{Zn}$ & B \\
\hline & \multicolumn{5}{|c|}{$(\%)$} & \multicolumn{2}{|c|}{ ppm } \\
\hline $\mathrm{Zn}_{0} \mathrm{~B}_{0}$ & 3.85 & 20.4 & 0.22 & 0.35 & 0.09 & 24.1 & 26.3 \\
\hline $\mathrm{Zn}_{0} \mathrm{~B}_{1}$ & 3.93 & 20.8 & 0.23 & 0.36 & 0.08 & 24.3 & 26.2 \\
\hline $\mathrm{Zn}_{0} \mathrm{~B}_{1.5}$ & 3.91 & 20.7 & 0.22 & 0.35 & 0.10 & 24.0 & 26.8 \\
\hline $\mathrm{Zn}_{0} \mathrm{~B}_{2}$ & 3.98 & 21.1 & 0.24 & 0.34 & 0.09 & 24.5 & 27.1 \\
\hline $\mathrm{Zn}_{1} \mathrm{~B}_{0}$ & 3.87 & 20.5 & 0.23 & 0.35 & 0.11 & 23.6 & 25.9 \\
\hline $\mathrm{Zn}_{1} \mathrm{~B}_{1}$ & 4.03 & 21.4 & 0.24 & 0.38 & 0.12 & 25.1 & 27.3 \\
\hline $\mathrm{Zn}_{1} \mathrm{~B}_{1.5}$ & 4.13 & 21.9 & 0.23 & 0.37 & 0.11 & 25.8 & 27.8 \\
\hline $\mathrm{Zn}_{1} \mathrm{~B}_{2}$ & 4.25 & 22.5 & 0.26 & 0.39 & 0.13 & 26.1 & 27.9 \\
\hline $\mathrm{Zn}_{2} \mathrm{~B}_{0}$ & 4.10 & 21.7 & 0.24 & 0.40 & 0.11 & 25.3 & 26.2 \\
\hline $\mathrm{Zn}_{2} \mathrm{~B}_{1}$ & 4.31 & 22.8 & 0.25 & 0.41 & 0.13 & 24.9 & 26.9 \\
\hline $\mathrm{Zn}_{2} \mathrm{~B}_{1.5}$ & 4.36 & 23.1 & 0.27 & 0.42 & 0.14 & 25.7 & 27.0 \\
\hline $\mathrm{Zn}_{2} \mathrm{~B}_{2}$ & 4.41 & 23.4 & 0.28 & 0.43 & 0.15 & 26.1 & 25.9 \\
\hline $\mathrm{Zn}_{3} \mathrm{~B}_{0}$ & 4.12 & 21.8 & 0.26 & 0.36 & 0.13 & 25.1 & 26.4 \\
\hline $\mathrm{Zn}_{3} \mathrm{~B}_{1}$ & 4.06 & 21.5 & 0.27 & 0.37 & 0.14 & 25.5 & 28.3 \\
\hline $\mathrm{Zn}_{3} \mathrm{~B}_{1.5}$ & 4.49 & 23.8 & 0.28 & 0.43 & 0.15 & 26.2 & 29.4 \\
\hline $\mathrm{Zn}_{3} \mathrm{~B}_{2}$ & 4.56 & $24.1 \mathrm{a}$ & 0.29 & 0.45 & 0.16 & 27.5 & 31.2 \\
\hline $\mathrm{CV}(\%)$ & 4.76 & 4.74 & 8.23 & 5.69 & 12.0 & 1.47 & 1.32 \\
\hline $\operatorname{LSD}(0.05)$ & 0.33 & 1.75 & 0.04 & 0.04 & 0.025 & 0.62 & 0.61 \\
\hline
\end{tabular}




\section{Main effects of zinc}

Different levels of zinc demonstrated significant variation in yields of fieldpea (Table 4). The seed yield increased with increasing $\mathrm{Zn}$ rates. The seed yields (mean of two years) in different $\mathrm{Zn}$ rates $\left(0,1,2\right.$ and $\left.3 \mathrm{~kg} \mathrm{ha}^{-1}\right)$ were 1142, 1303, 1397 and $1488 \mathrm{~kg} \mathrm{ha}^{-1}$, respectively. Hence the seed yields due to 2 and $3 \mathrm{~kg} \mathrm{Zn}$ $\mathrm{ha}^{-1}$ were found statistically similar particularly for the $1^{\text {st }}$ year. The stover yields due to 2 and $3 \mathrm{~kg} \mathrm{Zn} \mathrm{ha}^{-1}$ were a similar trend of seed yield. It was observed that the yield increased with the increase of $\mathrm{Zn}$ level up to $3 \mathrm{~kg} \mathrm{ha}^{-1}$. Similar trend was also reported by Kasthurikrishna and Ahlawat (2000). The yield benefits in terms of percentage varied from 14.1 to $30.3 \%$ over the control treatment.

Table 4. Main effects of zinc on the yields of fieldpea

\begin{tabular}{c|c|c|c|c|c|c|c}
\hline \multirow{2}{*}{$\begin{array}{c}\text { Zinc level } \\
\left(\mathrm{kg} \mathrm{ha}^{-1}\right)\end{array}$} & \multicolumn{2}{|c|}{ Seed yield $\left(\mathrm{kg} \mathrm{ha}^{-1}\right)$} & \multirow{2}{*}{\begin{tabular}{c} 
\% Yield \\
increment \\
\cline { 7 - 9 }
\end{tabular}} & $1^{\text {st }} \mathrm{yr}$ & $2^{\text {nd }} \mathrm{yr}$ & Mean & \multicolumn{3}{|c}{ Stover yield $\left(\mathrm{kg} \mathrm{ha}^{-1}\right)$} \\
\hline $\mathrm{Zn}_{0}$ & 1084 & 1200 & 1142 & - & 3028 & 3033 & 3031 \\
$\mathrm{Zn}_{1}$ & 1192 & 1414 & 1303 & 14.1 & 3288 & 3550 & 3419 \\
$\mathrm{Zn}_{2}$ & 1312 & 1482 & 1397 & 22.3 & 3605 & 3678 & 3642 \\
$\mathrm{Zn}$ & 1386 & 1589 & 1488 & 30.3 & 3747 & 4012 & 3880 \\
\hline $\mathrm{CV}(\%)$ & 5.58 & 3.82 & - & & 6.94 & 4.52 & - \\
$\mathrm{LSD}(0.05)$ & 98 & 54 & - & & 335 & 161 & - \\
\hline
\end{tabular}

Zinc played encouraging role on nodulation of fieldpea. At $32 \mathrm{DAS}$, the number of active nodules per plant ranged from 9.09 to 13.5, at 47 DAS, 21.6 to 27.3 and at 62 DAS, it was 26.9 to 35.9 , respectively. Furthermore, at 77 DAS, it varied from 19.8 to 25.5. The maximum number of nodules per plant was found with the application of $\mathrm{Zn}$ at $3 \mathrm{~kg} \mathrm{ha}^{-1}$ for all the nodule collection dates. The minimumt number of nodules per plant was recorded from Zn control plot (Table 5).

Table 5. Main effect of zinc on nodulation of fieldpea (2-year's pooled data)

\begin{tabular}{c|c|c|c|c}
\hline $\begin{array}{c}\text { Zinc level } \\
\left(\mathrm{kg} \mathrm{ha}^{-1}\right)\end{array}$ & $\begin{array}{c}\text { No. of nodules } \\
\text { at 32 DAS }\end{array}$ & $\begin{array}{c}\text { No. of nodules at } \\
\text { 47 DAS }\end{array}$ & $\begin{array}{c}\text { No. of nodules at } \\
\text { 62 DAS }\end{array}$ & $\begin{array}{c}\text { No. of nodules at } \\
\text { 77 DAS }\end{array}$ \\
\hline $\mathrm{Zn}_{0}$ & 9.09 & 21.6 & 26.9 & 19.8 \\
$\mathrm{Zn}_{1}$ & 11.3 & 23.2 & 29.6 & 24.5 \\
$\mathrm{Zn}_{2}$ & 11.9 & 25.1 & 32.7 & 25.5 \\
$\mathrm{Zn}_{3}$ & 13.5 & 27.3 & 35.9 & 24.9 \\
\hline $\mathrm{CV}(\%)$ & 3.80 & 3.14 & 1.82 & 4.80 \\
$\mathrm{LSD}(0.05)$ & 0.44 & 0.76 & 0.57 & 1.13 \\
\hline
\end{tabular}


In case of nutrients content, the highest $\mathrm{N}$, protein, $\mathrm{P}, \mathrm{K}, \mathrm{S}, \mathrm{Zn}$ and $\mathrm{B}$ contents $4.31 \%, 22.8 \%, 0.28 \%, 0.41 \%, 0.14 \%, 26.1 \mathrm{ppm}$ and $28.8 \mathrm{ppm}$, respectively were recorded with $3 \mathrm{~kg} \mathrm{ha}^{-1} \mathrm{Zn}$ rate (Table 6). Proper doses of zinc application may enhance the synthesis of carbohydrates, nutrient and protein content and their transport to the site of seed formation (Mali et al., 2003).

Table 6. Main effects of zinc and boron on $\mathrm{N}$, protein, $\mathrm{P}, \mathrm{K}, \mathrm{S}, \mathrm{Zn}$ and $\mathrm{B}$ contents of fieldpea seed (2-years pooled data)

\begin{tabular}{|c|c|c|c|c|c|c|c|}
\hline \multirow{3}{*}{$\begin{array}{c}\text { Zinc levels } \\
\left(\mathrm{kg} \mathrm{ha}^{-1}\right)\end{array}$} & \multicolumn{7}{|c|}{ Nutrient content in seed } \\
\hline & $\mathrm{N}$ & Protein & $\mathrm{P}$ & $\mathrm{K}$ & $\mathrm{S}$ & $\mathrm{Zn}$ & B \\
\hline & \multicolumn{5}{|c|}{$(\%)$} & \multicolumn{2}{|c|}{$\mathrm{ppm}$} \\
\hline $\mathrm{Zn}_{0}$ & 3.91 & 20.8 & 0.23 & 0.35 & 0.09 & 24.2 & 26.5 \\
\hline $\mathrm{Zn}_{1}$ & 4.07 & 21.6 & 0.24 & 0.37 & 0.12 & 25.1 & 26.6 \\
\hline $\mathrm{Zn}_{2}$ & 4.30 & 22.7 & 0.26 & 0.40 & 0.13 & 25.5 & 27.2 \\
\hline $\mathrm{Zn}_{3}$ & 4.31 & 22.8 & 0.28 & 0.41 & 0.14 & 26.1 & 28.8 \\
\hline $\mathrm{CV}(\%)$ & 3.16 & 3.13 & 1.29 & 3.09 & 10 & 1.78 & 1.31 \\
\hline LSD (0.05) & 0.13 & 0.69 & 3.22 & 0.02 & 0.02 & 0.45 & 0.36 \\
\hline
\end{tabular}

\section{Main effects of boron}

The seed yield ranged from 1132 to $1446 \mathrm{~kg} \mathrm{ha}^{-1}$, the highest yield in the 2nd year being observed at $2 \mathrm{~kg} \mathrm{ha}^{-1} \mathrm{~B}$ application. In the $1^{\text {st }}$ year, the seed yield was found highest at $B$ rate of $1.5 \mathrm{~kg} \mathrm{ha}^{-1}$ was statistically similar to $B$ rate of $2 \mathrm{~kg} \mathrm{ha}^{-1}$. The lowest yield was recorded in the control treatment (Table 7). The trend of stover yield showed the similar of seed yield. Boron influences reproductive growth of crop (Chatterjee and Bandyopadhyay, 2015).

Table 7. Main effects of boron on the yields of fieldpea

\begin{tabular}{|c|c|c|c|c|c|c|c|}
\hline \multirow{2}{*}{$\begin{array}{c}\text { Boron } \\
\text { level } \\
\left(\mathrm{kg} \mathrm{ha}^{-1}\right)\end{array}$} & \multicolumn{3}{|c|}{ Seed yield $\left(\mathrm{kg} \mathrm{ha}^{-1}\right)$} & \multirow{2}{*}{$\begin{array}{c}\% \text { Yield } \\
\text { increment } \\
\text { over } \\
\text { control }\end{array}$} & \multicolumn{3}{|c|}{ Stover yield $\left(\mathrm{kg} \mathrm{ha}^{-1}\right)$} \\
\hline & $1^{\text {st }} \mathrm{yr}$ & $2^{\text {nd }} \mathrm{yr}$ & Mean & & $1^{\text {st }} \mathrm{yr}$ & $2^{\text {nd }} \mathrm{yr}$ & Mean \\
\hline $\mathrm{B}_{0}$ & 1065 & 1198 & 1132 & - & 2975 & 3086 & 3031 \\
\hline $\mathrm{B}_{1}$ & 1218 & 1418 & 1318 & 16.4 & 3408 & 3533 & 3471 \\
\hline $\mathrm{B}_{1.5}$ & 1361 & 1510 & 1436 & 26.6 & 3707 & 3744 & 3726 \\
\hline $\mathrm{B}_{2-}$ & 1331 & 1560 & 1446 & 27.7 & 3577 & 3910 & 3744 \\
\hline $\mathrm{CV}(\%)$ & 5.58 & 3.82 & - & & 6.94 & 4.52 & - \\
\hline $\begin{array}{c}\text { LSD } \\
(0.05)\end{array}$ & 64.6 & 43.8 & - & & 219 & 132 & - \\
\hline
\end{tabular}


The number of nodules per plant increased with increasing the rates of $\mathrm{B}$ application. The number of nodules per plant at 32 DAS ranged from 9.84 to 14.6, at 47 DAS from 22.1 to 25.9 , at 62 DAS from 28.3 to 33.7 and at 77 DAS, it varied from 22.2 to 24.9 over the treatments. The maximum number of nodules per plant was recorded from the application of $2 \mathrm{~kg} \mathrm{~B} \mathrm{ha}^{-1}$ across the nodule collection dates (Table 8). Noor and Hossain (2007) reported that adequate boron application positively influenced effective nodulation and nitrogen fixation in legumes.

Table 8. Main effects of boron on nodulation of fieldpea (2- year's pooled data)

\begin{tabular}{c|c|c|c|c}
\hline $\begin{array}{c}\text { Boron level } \\
\left(\mathrm{kg} \mathrm{ha}^{-1}\right)\end{array}$ & $\begin{array}{c}\text { No. of nodules } \\
\text { at 32 DAS }\end{array}$ & $\begin{array}{c}\text { No. of nodules at } \\
\text { 47 DAS }\end{array}$ & $\begin{array}{c}\text { No. of nodules at } \\
\text { 62 DAS }\end{array}$ & $\begin{array}{c}\text { No. of nodules at } \\
\text { 77 DAS }\end{array}$ \\
\hline $\mathrm{B}_{0}$ & 9.84 & 22.1 & 28.3 & 22.2 \\
$\mathrm{~B}_{1}$ & 11.4 & 23.9 & 30.9 & 22.9 \\
$\mathrm{~B}_{1.5}$ & 12.0 & 25.2 & 32.2 & 24.5 \\
$\mathrm{~B}_{2}$ & 12.6 & 25.9 & 33.7 & 24.9 \\
\hline $\mathrm{CV}(\%)$ & 3.80 & 3.14 & 1.82 & 4.80 \\
LSD $(0.05)$ & 0.49 & 0.67 & 1.09 & 0.76 \\
\hline
\end{tabular}

Different nutrient (N, P, K, S, Zn and B) and protein contents in seed of fieldpea was influenced significantly due to application of different rates of B (Table 9). The highest nutrient content $(4.30 \% \mathrm{~N}, 0.27 \% \mathrm{P}, 0.40 \% \mathrm{~K}, 0.13 \% \mathrm{~S}, 26 \mathrm{ppm} \mathrm{Zn}$ and $28 \mathrm{ppm} \mathrm{B}$ ) in seed were obtained with application of $2 \mathrm{~kg} \mathrm{~B} \mathrm{ha}^{-1}$ that was statistically identical to $1.5 \mathrm{~kg} \mathrm{~B} \mathrm{ha}^{-1}$ except $\mathrm{P}$ and $\mathrm{Zn}$ contents. The lowest nutrient content in seed was noted for B control treatment (Table 9). Regarding protein content, the highest protein content in seed $(22.8 \%)$ was obtained with 2 $\mathrm{kg} \mathrm{B} \mathrm{ha}{ }^{-1}$ application that was statistically similar to application of $1.5 \mathrm{~kg} \mathrm{~B} \mathrm{ha}$ ${ }^{1}$ (Table 9).

Table 9. Main effects of zinc and boron on N, protein, P, K, S, Zn and B contents of fieldpea seed (2-years pooled data)

\begin{tabular}{c|c|c|c|c|c|c|c}
\hline \multirow{2}{*}{$\begin{array}{c}\text { Boron levels } \\
\left(\mathrm{kg} \mathrm{ha}^{-1}\right)\end{array}$} & $\mathrm{N}$ & Protein & $\mathrm{P}$ & $\mathrm{K}$ & $\mathrm{S}$ & $\mathrm{Zn}$ & $\mathrm{B}$ \\
\cline { 2 - 9 } & \multicolumn{7}{c}{$(\%)$} \\
\hline $\mathrm{B}_{0}$ & 3.98 & 21.1 & 0.24 & 0.37 & 0.11 & 24.5 & 26.2 \\
$\mathrm{~B}_{1}$ & 4.08 & 21.6 & 0.25 & 0.38 & 0.12 & 24.9 & 27.2 \\
$\mathrm{~B}_{1.5}$ & 4.22 & 22.4 & 0.25 & 0.39 & 0.13 & 25.4 & 27.7 \\
$\mathrm{~B}_{2}$ & 4.30 & 22.8 & 0.27 & 0.40 & 0.13 & 26.0 & 28.0 \\
\hline $\mathrm{CV}(\%)$ & 3.16 & 3.13 & 1.29 & 3.09 & 10 & 1.78 & 1.31 \\
$\mathrm{LSD}(0.05)$ & 0.17 & 0.87 & 0.02 & 0.02 & 0.02 & 0.31 & 0.30 \\
\hline
\end{tabular}




\section{Conclusion}

This study indicates that application of $\mathrm{Zn}$ at $3 \mathrm{~kg} \mathrm{ha}^{-1}$ and $\mathrm{B}$ at 1.5 or $2 \mathrm{~kg} \mathrm{ha}^{-1}$ significantly increased the seed yield of fieldpea. The maximum nodulation and protein percentage was found in $\mathrm{Zn}_{3} \mathrm{~B}_{2}$ treatment followed by $\mathrm{Zn}_{3} \mathrm{~B}_{1.5}$ treatment. Similarly nutrient (N, P, K, S, Zn and B) contens were also higher in the treatment combination of $\mathrm{Zn}_{3} \mathrm{~B}_{2}$ followed by $\mathrm{Zn}_{3} \mathrm{~B}_{1.5}$. Thus, results of the experiment suggest that the application of $Z_{3} B_{2}$ along with $N_{12} P_{18} K_{30} S_{10} k g$ ha${ }^{1}$ is needed for yield maximization of fieldpea.

\section{References}

Agrawal, M. M. and C. P. Sharma. 2005. Effect of sulphur and molybdenum with Rhizobium and PSB on yield and nutrient uptake in chick pea. Farm Science J. 15: 20-2.

Bray, R.H. and L.T. Kurtz. 1945. Determination of total, organic and available forms of phosphorus in soils. Ibid. 59:39-45.

Bremner, J.M. and C.S. Mulvaney. 1982. Total nitrogen. In A. L. Page, R. H. Miller, D. R. Keeney (Eds.), Methods of Soil Analysis (Part 2, 2nd ed., Pp. 599-622). Am. Soc. Agron., Madison, USA.

Chatterjee, R. and S. Bandyopadhyay. 2015. Effect of boron, molybdenum and biofertilizers on growth and yield of cowpea (Vigna unguiculata L. Walp.) in acid soil of eastern Himalayan region. Journal of the Saudi Society of Agricultural Sciences. 16: 332-336. http://dx.doi.org/10.1016/j.jssas.2015.11.001.

Dixit, G.P. 2002. Improved Varieties of Field pea in India. Indian Institute of Pulses Research, Kanpur.

Erman, M., B. Yildirim, T. Necat and C. Fatih. 2009. Effect of phosphorus application and Rhizobium inoculation on the yield, noducation and nutrient uptake in field pea (Pisum sativum sp. arvense L.). Journal of Animal and Veterinary Advances. 8(2): 301-304.

FAO. 2018. Analysis of Protein. Food and agriculture Origination publication, FAO Food and Nutrition Paper 14/7. Centre for Food Safety, UN. http://www.cfs.gov.hk/english/programme/programme_nifl/files/Analysis_of_Protei n.pdf (accessed on 08 January 2018).

Fox, R.L., R.A. Olsen and H.F. Rhoades. 1964. Evaluating the sulphur status of soil by plant and soil test. Soil Science Society of America Proc, 28, 243-246. https://doi.org/10.2136/sssaj1964.03615995002800020034x.

FRG. 2012. Fertilizer Recommendation Guide. Published by Bangladesh Agricultural Research Council, Dhaka, Bangladesh.

Jackson, M.L. 1973. Soil Chemical Analysis (P. 498). Prentice Hall of India Private Limited, New Delhi.

Jahiruddin, M. 2015. Book. Zinc and boron deficiency in crops and their management in Bangladesh. Department of Soil Science, Bangladesh Agricultural University, Mymensingh, Pp. 1-27. 
Karim, M.R. 2016. Response of lentil to zinc, boron and molybdenum application in terrace soil of Bangladesh. MS Thesis, Deprtment of Agronomy, Bangabandhu Sheikh Mujibur Rahman Agricultural University, Salna, Gazipur-1706.

Kasturikrishna, S. and I.P.S. Ahlawat. 2000. Effect of moisture stress and phosphorus, sulphur and zinc fertilizer on growth and development of pea (Pisum sativum). Indian Journal of Agronomy 45(2): 353-356.

Lindsay, W.L. and W.A. Norvell. 1978. Development of DTPA soil test for zinc, iron, manganese and copper. Soil science Society of American. J. 42: 421-8.

Mali, G.C., N.N. Sharma, H.K. Acharya, H.K. Gupta and P.K. Gupta. 2003. Response of pigeon pea to $\mathrm{S}$ and $\mathrm{Zn}$ fertilization on vertisols in south-eastern plain of Rajasthan. Advances in Arid Legumes Research, pp. 267-271. Indian Arid Legumes Society, Scientific Publishers (India), Jodhpur.

Márquez-Quiroz, C., E. De-la-Cruz-Lázaro, R. Osorio-Osorio and E. Sánchez-Chávez. 2015. Biofortification of cowpea beans with iron: iron's influence on mineral content and yield. J. Soil Sci. Plant Nutr. 15 (4): 839-847.

Nelson, D.W. and L.E. Sommers. 1982. Total carbon, organic carbon and organic matter. In A. L. Page, R. H. Miller, \& D. R. Keeney (Eds.), Methods of Soil Analysis (Part 2, 2nd ed., pp. 539-580). Am. Soc. of Agron., Madison, USA.

Noor, S.S. and Hossain M.A. 2007. Effects of boron and molybdenum on the yield of chickpea. J. Agric. Rural Dev. 5 (1\&2):17-24.

Page, A.L., R.H. Miller and D.Keeney (Eds.).1982. Agronomy Series 9 ASA, SSSA. Methods of Soil Analysis (Part 2, 2nd ed., pp. 403-427). Am. Soc. of Agron., Madison, USA.

Patel, M.M., I.C. Patel, R.I Patel and S. Acharya. 2011. Effect of Zinc and Iron on Yield and Yield Attributes of Rainfed Cowpea (Vigna unguiculata L. Walp). Annals of Arid Zone. 50(1): 17-19.

Persson, Jan-Ake, Wennerholm M. and O’Halloram S. 2008. Handbook for Kjeldahl Digestion. Published by FOSS, DK-3400 Hilleroed, Denmark. ISBN 91-630-3471-9.

Piper, C. 1966. Soil and Plant Analysis. Adelaide University Press, Australia.

Raj, S. 1985. An introduction to physiology of field crops, Oxford and IBH Publishing Co., New Delhi. Pp. 94-97.

Rashid, M.M. 2001. Agroecological characteristics of Bangladesh. In: M.A. Wadud Mian, F.M.Maniruzzaman, M.A. Sattar, M.A. Aziz Miah, S.K. Paul and K.R. Haque (eds.) Agricultural Research in Bangladesh in the 20th Century. Bangladesh Agricultural Research Council \& Bangladesh Academy of Agriculture, Dhaka. Pp. $37-42$.

Statistix 10. 1985. An Anlytical Software, Po Box 12185, Tallahassee, FL 32317, Copy right (C) 1985-2013.

URL: http://medwelljournals.com/abstract/?doi=javaa.2009.301.304

Valenciano, J.B., J.A. Bato and V. Marcelo. 2010. Response of chickpea (Cicer arientinum L.) yield to Zinc, boron and molybdenum application under pot conditions. Spanish Journal of Agricultural Research. 8: 797-807. 
